\title{
Alexander Charles Cumming, O.B.E., D.Sc., F.I.C.
}

Alexander Charles Cumming was born in Melbourne, Victoria, in I880. From Caulfield Grammar School he proceeded to the University of Melbourne, where he gained several scholarships and graduated as B.Sc., with First Class Honours in Chemistry, in 1902. During the two years following he held the Kernot and Dixon Research Scholarships and engaged in chemical research under Professor (later Sir) David Orme Masson and acted as demonstrator. In I904 he was awarded an $185 \mathrm{I}$ Exhibition Research Scholarship and spent the first year with Professor (later Sir) James Walker in Dundee and the second with Professor Abegg in Breslau. At this period (1905) he received the degree of D.Sc. of Melbourne University. The scholarship having been extended for a third year, he worked with Sir William Ramsay at University College, London, until appointed Lecturer at Birkbeck College in 1907. When James Walker came to Edinburgh as Professor of Chemistry, in 1908, he appointed Cumming to a Lecturership in the subject, a post that he held for nine years. During this period he was in charge of the Medical Practical Class and of the Senior Laboratories for Final Science students. In addition to the duties of the Lecturership, he engaged in research work upon various subjects of chemical, physico-chemical, and technical interest, and contributed papers to the Royal Societies of London and of Edinburgh, the Chemical Society and the Faraday Society, which were printed in their respective journals (see notice in Journ. Chem. Soc.).

$\mathrm{He}$ also entered upon extensive literary work, which took up much of his attention both during and subsequent to his connection with Edinburgh University. His Practical Chemistry for Medical Students appeared in I9II and passed through three editions. In collaboration with the late Dr Sydney A. Kay he produced a Text-book of Quantitative Chemical Analysis, which was highly successful from the first, and in the revised seventh edition (1939) remains a standard work on the subject. A valuable series of Chemical Monographs written by specialists and edited by Cumming appeared during the period 1913-22. The editing of a new issue of the six large volumes of Lunge's classical Sulphuric Acid and Alkali-the most extensive of Cumming's literary efforts-was carried out between 1923 and 1925 . He also revised in 1929 the third edition of The Technical Chemist's Handbook by the same author. 
The outbreak of the Great War in 19I4 formed a turning-point in Cumming's life. Filled with a desire to devote his energies to the assistance of the country, he offered his services to the Government as a chemist, with a view to the establishment of an explosives factory in the neighbourhood of Edinburgh. After negotiations and approval, in I9I 5 he proceeded, in conjunction with Professor James Walker and $\mathrm{Mr}$ John W. Romanes, to the fitting up in Broughton Road, Edinburgh, of the Lothian Chemical Company's Factory, of which he became manager, for the manufacture of trinitrotoluene (T.N.T.). In this enterprise, the initiative and also the working details of the manufacturing process were his own. The story of the factory is told in an interesting pamphletStarting a War-time Factory-which he circulated to friends after the war. The factory was a distinct success, and for about two years it turned out "T.N.T." "in large quantity and of the highest quality. Later the Government asked the company to build a larger factory in a safer area, and H.M. Factory, Craigleith, was built, and the production was continued there for some time. In recognition of his services, Cumming received the appointment of O.B.E. in 1918.

At the end of the war, Cumming returned to Edinburgh University for a short period as Lecturer on Technical Chemistry. In I92 I he went to Liverpool as consultant to Macfie \& Sons, Ltd., Sugar Refiners, of which company he became Managing Director three years later. $\mathrm{He}$ reorganised the factory, and remained there during fourteen strenuous years and until its closing in 1938 .

In recent years Cumming lived at Caldy, Cheshire, or at "Craigness," Glenisla, Perthshire. A world tour to Singapore, the Dutch Indies, Australia, New Zealand, and Canada was undertaken in 1938-39. He died suddenly on September 28, 1940, while staying in Wales.

Gifted with much force of character, Cumming was outstanding as a capable and confident teacher, a wise counsellor, a hard worker, and, to those who knew him well, a firm, constant, and sympathetic friend. His immediate circle have to mourn the passing of a devoted spouse and parent.

He was elected a Fellow in I9I4.

$$
\begin{aligned}
& \text { L. D. } \\
& \text { J. E. M. }
\end{aligned}
$$

